\title{
Photoacclimation, growth and distribution of massive coral species in clear and turbid waters
}

\author{
Sebastian J. Hennige ${ }^{1}$, David J. Smith ${ }^{1}$, Rupert Perkins ${ }^{2}$, Mireille Consalvey ${ }^{3}$, \\ David M. Paterson ${ }^{4}$, David J. Suggett ${ }^{1, *}$ \\ ${ }^{1}$ Coral Reef Research Unit, Department of Biological Sciences, University of Essex, Colchester CO4 3SQ, UK \\ ${ }^{2}$ School of Earth, Ocean and Planetary Sciences, University of Cardiff, Cardiff CF10 3YE, UK \\ ${ }^{3}$ National Institute of Water and Atmospheric Research, Private Bag 14-901, Wellington, New Zealand \\ ${ }^{4}$ Sediment Ecology Research Group, Gatty Marine Laboratory, University of St. Andrews, Fife KY16 8LB, UK
}

\begin{abstract}
Massive coral species play a key role in coral reef ecosystems, adding significantly to physical integrity, long term stability and reef biodiversity. This study coupled the assessment of the distribution and abundance of 4 dominant massive coral species, Diploastrea heliopora, Favia speciosa, F. matthaii and Porites lutea, with investigations into species-specific photoacclimatory responses within the Wakatobi Marine National Park of southeast Sulawesi, Indonesia, to determine the potential of photoacclimation to be a driver of biological success. For this, rapid light curves using pulse amplitude modulated (PAM) chlorophyll a fluorescence techniques were employed with additional manipulations to circumvent differences of light quality and absorption between species and across environmental gradients. $P$. lutea was examined over a range of depths and sites to determine patterns of photoacclimation, and all 4 species were assessed at a single depth between sites for which long-term data for coral community structure and growth existed. Light availability was more highly constrained with depth than between sites; consequently, photoacclimation patterns for $P$. lutea appeared greater with depth than across environmental gradients. All 4 species were found to differentially modify the extent of non-photochemical quenching to maintain a constant photochemical operating efficiency (qP). Therefore, our results suggest that these massive corals photoacclimate to ensure a constant light-dependent rate of reduction of the plastoquinone pool across growth environments.
\end{abstract}

KEY WORDS: Chlorophyll a fluorescence · Zooxanthellae · PAM · Photoacclimation · Massive coral · Indo-Pacific

Resale or republication not permitted without written consent of the publisher

\section{INTRODUCTION}

Scleractinian corals are integral to reef systems and play a fundamental role in reef structure. For many reefs, massive scleractinian corals are often among the most abundant species present (Holl 1983, Kenyon et al. 2006) and, importantly, are known to be relatively tolerant of environmental disturbance events and disease when compared with non-massive coral species (West \& Salm 2003, Kenyon et al. 2006). As such, massive species are thought to increase reef resilience (Hoegh-Guldberg \& Salvat 1995, Loya et al. 2001, Kenyon et al. 2006) and likely represent an important group of corals for reef structure, functioning and resilience in light of future environmental perturbations.

As with other corals, symbiotic dinoflagellate microalgae, collectively termed zooxanthellae, are harboured within the gastrodermis of the host coral (Trench 1979, Muscatine 1990). Optimisation of photosynthesis by these zooxanthellae is achieved in part through the process of photoacclimation, an important process if reef building cnidaria are to successfully colonise and ultimately flourish within otherwise nutrient-poor waters (Arias-Gonzalez et al. 1997). Photoacclimation describes the phenotypic 
adjustments that arise following a change in light environment (Falkowski \& LaRoche 1991) and is genetically constrained (MacIntyre et al. 2002). Zooxanthellae (in hospite and isolated) photoacclimate in the same way as for many other microalgae, by adjusting various cellular constituents including pigmentation and number of 'reaction centres' for light harvesting (Falkowski \& Dubinsky 1981, Iglesias-Prieto \& Trench 1994, Robison \& Warner 2006). However, these patterns of photoacclimation have been largely deduced using cultures of zooxanthellae isolated from their coral host. Quantifying zooxanthellae photoacclimation in hospite is more problematic. In particular, the methods employed are often destructive to the coral and thus not practical to describe broad ecosystem processes (Falkowski \& Dubinsky 1981). These techniques also require removal of the corals from their habitat and may thus perturb their natural physiological state (Jones \& Hoegh-Guldberg 2001). Instead, researchers have turned towards the use of nondestructive chlorophyll a ( $\mathrm{chl}$ a) fluorescence induction techniques, which are popular for examining phytoplankton and higher plant photophysiology, to investigate coral photophysiology; in particular pulse amplitude modulation (PAM) (Ralph et al. 1999, Ralph \& Gademann 2005) and fast repetition rate (FRR) (Gorbunov et al. 2001) fluorescence.

Chl a fluorescence induction provides information specific to the dissipation of absorbed excitation energy by photosystem II (PSII) (Falkowski \& Raven 1997). As a result, PAM and FRR fluorescence enables calculation of the PSII electron transport rate and estimation of the (gross) $\mathrm{O}_{2}$ that is produced by photosynthesis (Gorbunov et al. 2001, Kromkamp \& Forster 2003, Suggett et al. 2003, Suggett et al. 2007). Since the mid 1990s, papers have described characteristics of PSII fluorescence in corals following environmental changes in reef systems (Warner et al. 1999, Gorbunov et al. 2001, Lesser 2004). Two approaches are commonly used, 'dark-adapted' and/or 'ambient light' fluorescence measurements. Dark-adapted fluorescence indicates the physiological state to which cells have acclimated via reorganisation of cellular constituents; as photoprotective mechanisms are relaxed, PSII reaction centres are 'open' and the electron transport chain is oxidised (Ralph \& Gademann 2005). Under ambient light, fluorescence indicates the capacity of cells to utilise absorbed excitation energy (Falkowski \& Raven 1997, Lesser \& Gorbunov 2001, Ralph \& Gademann 2005). Both approaches are therefore particularly important depending on the time scale of interest, as the light environment on a reef changes over the long term (wet season: OctoberMarch; dry season: April-September) and the short term (diurnal variation).
Conventionally, the photosynthesis light-response can be characterised from changes of $\mathrm{O}_{2}$ evolution (Falkowski \& Raven 1997) or fluorescence (Suggett et al. 2003, Suggett et al. 2007) following a gradient of increasing actinic light intensity. Photosynthesis is said to have reached steady state once constant with light intensity (over a time scale of minutes) (Suggett et al. 2003, Ralph \& Gademann 2005). Some studies have measured steady state fluorescence relative to in situ ambient PAR to great effect (Gorbunov et al. 2001, Lesser \& Gorbunov 2001, Winters et al. 2003). However, achieving steady state over a series of light steps can take up to an hour; a period of time that is generally impractical for investigating corals in situ where diving must be employed. To circumvent this limitation, rapid light curves (RLC) were introduced to assay the light-response of zooxanthellae photosynthesis in hospite and indicates the actual (over a time scale of seconds) as opposed to the steady state of photosynthesis (Ralph \& Gademann 2005). RLCs provide a useful means for comparing dissipation of absorbed excitation energy on a relative basis by measuring the electron transport rate (ETR) through PSII. By measuring these (relative) ETRs over periods of increasing light intensity, information regarding the photosynthetic activity of the organism under light limitation and light saturation can be obtained as well as the light saturation point, i.e. the organism's capacity for photosynthesis before it is light-saturated. The proportion of absorbed photon energy used to drive photochemistry (photochemical quenching, qP) or converted to heat (non-photochemical quenching, qN or NPQ) can thus be calculated from these RLCs. However, even on a relative basis, RLCs can prove difficult to interpret since, under different environmental conditions or between coral species, the amount of photosynthetically useable radiation (PUR) available to the organism may differ (MacIntyre et al. 2002, Suggett et al. 2007), but will not be not accounted for by RLCs. In order to account for PUR, absorbance of the coral and Symbiodinium would have to be quantified (Kirk 1994, Enriquez et al. 2005, Stambler \& Dubinsky 2005).

The present study used RLCs to examine photoacclimation characteristics of massive corals in the Wakatobi Marine National Park in southeast Sulawesi, Indonesia, between sites of differing light availability. Massive corals of the Porites genus are amongst the most abundant corals present on Indonesian reefs (Holl 1983). Porites also appear to have substantial resistance to light stress and disease (Hoegh-Guldberg \& Salvat 1995, Loya et al. 2001, Kenyon et al. 2006). As a result, we focused on the massive coral $P$. lutea (Milne Edwards \& Haime 1860), which was ubiquitously distributed across our sample sites. 
Photoacclimation was characterised for Porites lutea over a bathymetric range (5 to $17 \mathrm{~m}$ ) and between sites of differing turbidity using standard PAM techniques with simple manipulations to circumvent differences of light quality across environmental gradients and absorption differences between individual corals. These characteristics were compared with those of other massive species (Diploastrea heliopora, Favia matthaii and F. speciosa). Photoacclimation data were then combined with coral community structure data to establish the role photoacclimatory ability plays in driving distribution and abundance of these species across environmental gradients.

\section{MATERIALS AND METHODS}

Sample sites. All sites were situated in a remote island group within the Wakatobi Marine National Park of the Tukang Besi archipelago, southeast Sulawesi, Indonesia. Two sites were chosen: the reef slope of a relatively turbid reef adjacent to a local Bajo community (Site 1, $5^{\circ} 28^{\prime} \mathrm{S}, 123^{\circ} 44^{\prime} \mathrm{E}$ ) and the upper reef slope of a low-turbidity reef off Hoga Island (Site 2, $5^{\circ} 28^{\prime} \mathrm{S}, 1^{\circ} 3^{\circ} 45^{\prime} \mathrm{E}$ ) (Fig. 1) as described previously by Crabbe \& Smith (2005). The low-turbidity site (Site 2) was characterised by a lower attenuation coefficient $\left(K_{d(\mathrm{PAR})}=0.13 \pm 0.01 \mathrm{~m}^{-1}\right)$ than observed for the turbid site (Site 1) $\left(K_{d(\mathrm{PAR})}=0.20 \pm\right.$ $\left.0.02 \mathrm{~m}^{-1} ; \mathrm{t}=5.86, \mathrm{n}=4, \mathrm{p}<0.001\right)$, measured using the Diving-PAM's photosynthetically active radiation (PAR) sensor (see 'Materials and methods-Diving PAM fluorometry'). Differences in $K_{d(\mathrm{PAR})}$ between sites using PAR were consistent with differences observed in previous studies on sedimentation rates that were ca. a factor of 4 higher at Site 1 than at Site 2 (Crabbe \& Smith 2005, D. J. Smith unpubl.). Both sites were characterised by the presence of the coral species Diploastrea heliopora, Favia speciosa, F. matthaii and Porites lutea. Average water column (0 to $18 \mathrm{~m}$ ) temperature ranged from 25 to $28^{\circ} \mathrm{C}$ during data collection (measured using HOBO [Onset] data loggers over the bathymetric range) but can range from 24 to $31^{\circ} \mathrm{C}$ over the year. There was no recorded thermocline within the coral experimental depth range over the course of the investigations. Bathymetric comparisons of $P$. lutea ( 0 to $17 \mathrm{~m}$ ) were conducted in 2004 and the crossspecies comparisons $(10 \mathrm{~m})$ in 2006.

Coral growth and distribution. Yearly coral growth rates were determined in permanent quadrats $(n=3)$ established at each test site in 2005 at a depth of ca. 8 to $10 \mathrm{~m}$. Permanent quadrats were 10 by $2 \mathrm{~m}$ and were separated by ca. $50 \mathrm{~m}$. This quadrat size was deemed appropriate through preliminary investigations that examined the density of coral colonies at each of the sites. Triplicate line-intercept transects along the top, middle and bottom of the quadrats (total length $30 \mathrm{~m}$ ) returned a percentage cover of coral that was comparable to the long standing extensive coral monitoring programme that utilized a continual $50 \mathrm{~m}$ transect $(\mathrm{n}=$ 108, D. Smith et al. unpubl. data). Quadrats were therefore used to provide a good estimate of coral colony density that avoided the problem of repeated colony counts when using the transect method. Dimensions of test corals were recorded (length, width and height) in 2005 and 2006 to calculate surface area of coral growth $\left(\mathrm{cm}^{2}\right)$. Benthic life forms were categorised according to English et al. (1997). Distribution and number of massive coral colonies was also recorded in each quadrat to determine abundance (\%) of target coral species relative to all other massive species present, which thus enabled intra- and interspecific comparisons between sites.

Diving PAM fluorometry. A Diving-Pulse Amplitude Modulation (Diving-PAM) fluorometer (Walz), which has an external PAR sensor, was used for all measurements. PAR, termed here as light intensity (E) throughout, was measured in units of $\mu \mathrm{mol}$ photons $\mathrm{m}^{-2} \mathrm{~s}^{-1}$, between 380 and $710 \mathrm{~nm}$. Chl a fluorescence was stimulated by a pulse modulated red LED at $655 \mathrm{~nm}$ and detected by a PIN-photodiode via a long-pass filter

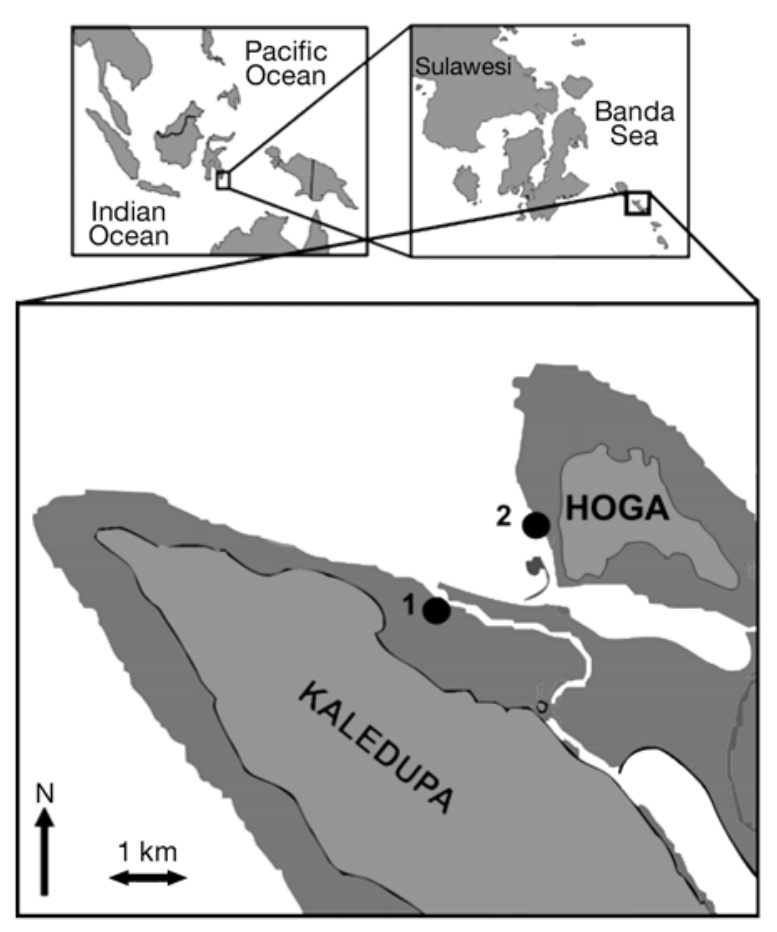

Fig. 1. Sample sites within the Wakatobi Marine National Park of the Tukang Besi archipelago, southeast Sulawesi, Indonesia. Site 1 (relatively turbid, $5^{\circ} 28^{\prime} \mathrm{S}, 123^{\circ} 44^{\prime} \mathrm{E}$ ) was located next to a Bajo village, Site 2 (low-turbidity, $5^{\circ} 28^{\prime} \mathrm{S}$, $123^{\circ} 45^{\prime}$ E) was located on the Hoga reef 
$(\lambda>710 \mathrm{~nm})$. A modified version of Walz's surface holder (Diving-SH) was attached to the free end of the fibre optic to standardise the distance between fibre optic tip and coral surface. The modified holder minimised physical disturbance of the coral polyps by having less surface area in contact with the colonies than the standard Diving-SH.

As with other PAM fluorometers, a modulated light source was used to determine the minimum or 'background' fluorescence yield when all PSII reaction centres are 'open' and in a state ready to receive excitation energy. A high intensity 'saturating' pulse of actinic light was then applied to stimulate multiple closures (turnover events) of the PSII reaction centres and reduction of the plastoquinone pool (Suggett et al. 2003, Baker \& Oxborough 2005, Consalvey et al. 2005). Under a fully relaxed, dark-adapted state, the minimum and maximum fluorescence yields measured are termed $F_{0}$ and $F_{\mathrm{m}}$ respectively (Table 1 ). Under actinic light, these fluorescence yields become modified and the steady state, minimum and maximum fluorescence observed are termed $F^{\prime}, F_{0}{ }^{\prime}$ and $F_{\mathrm{m}}{ }^{\prime}$. The dark-adapted maximum photochemical efficiency of exciton energy transfer to PSII reaction centres, $\left(F_{\mathrm{m}}-F_{0}\right) / F_{\mathrm{m}}$, termed $F_{\mathrm{v}} / F_{\mathrm{m}}$ (also called maximum quantum yield), is dimensionless (see reviews by Kromkamp \& Forster 2003,

Table 1. Parameters and definitions, adapted from Kromkamp \& Forster (2003) and Baker \& Oxborough (2005). All units are in instrument-specific values (fluorescence yields) or dimensionless (fluorescence ratios) unless stated otherwise

\begin{tabular}{|c|c|}
\hline Parameter & Definition \\
\hline$F_{0}$ & Minimum fluorescence yield - dark-adapted \\
\hline$F_{\mathrm{m}}$ & Maximum fluorescence yield - dark-adapted \\
\hline$F^{\prime}$ & Fluorescence yield - under actinic light \\
\hline$F_{\mathrm{v}}$ & Variable fluorescence yield $\left(F_{\mathrm{m}}-F_{0}\right)$ - dark-adapted \\
\hline$F_{\mathrm{v}}^{\prime}$ & Variable fluorescence yield $\left(F_{\mathrm{m}}{ }^{\prime}-F_{0}{ }^{\prime}\right)-$ under actinic light \\
\hline$F_{\mathrm{q}}^{\prime}$ & Fluorescence quenched $\left(F_{\mathrm{m}}^{\prime}-F^{\prime}\right)$ \\
\hline$F_{\mathrm{v}} / F_{\mathrm{m}}$ & Maximum photochemical efficiency of PSII - dark-adapted ${ }^{b}$ \\
\hline$F_{\mathrm{q}}^{\prime} / F_{\mathrm{m}}^{\prime}{ }^{\mathrm{a}}$ & $\begin{array}{l}\text { Effective photochemical efficiency of PSII photochemistry } \\
\left(F_{\mathrm{m}}{ }^{\prime}-F^{\prime}\right) / F_{\mathrm{m}}{ }^{\prime}-\text { under actinic light } \mathrm{c}^{\mathrm{C}}\end{array}$ \\
\hline$F_{\mathrm{q}}{ }^{\prime} / F_{\mathrm{m}}{ }^{\prime}(\max )$ & Derived maximum photochemical efficiency of PSII \\
\hline$F_{\mathrm{v}}{ }^{\prime} / F_{\mathrm{m}}{ }^{\prime}$ & $\begin{array}{l}\text { Quantum efficiency of exciton transfer to PSII (otherwise termed } \\
\text { non-photochemical quenching, qN) - under actinic light }\end{array}$ \\
\hline$F_{\mathrm{q}}{ }^{\prime} / F_{\mathrm{v}}{ }^{\prime}$ & $\begin{array}{l}\text { Photochemical operating efficiency of PSII (otherwise termed } \\
\text { photochemical quenching, qP) - under actinic light }\end{array}$ \\
\hline NPQ & $\left(F_{\mathrm{m}}-F_{\mathrm{m}}{ }^{\prime}\right) / F_{\mathrm{m}}{ }^{\prime} ;$ non-photochemical quenching \\
\hline$\alpha$ & $\begin{array}{l}\text { Describes the light-limited initial slope of a Rapid Light Curve } \\
\text { (dimensionless) }\end{array}$ \\
\hline$r \mathrm{ETR}^{\mathrm{MAX}}$ & $\begin{array}{l}\text { Maximum relative electron transport rate } \\
\left(\mu \mathrm{mol} \text { electrons } \mathrm{m}^{-2} \mathrm{~s}^{-1}\right)\end{array}$ \\
\hline $\mathrm{E}_{\mathrm{k}}$ & Light saturation coefficient ( $\mu \mathrm{mol}$ photons $\mathrm{m}^{-2} \mathrm{~s}^{-1}$ ) \\
\hline $\begin{array}{l}\text { a Also denot } \\
{ }^{\mathrm{b}} \text { Also callec } \\
\text { cAlso callec }\end{array}$ & $\begin{array}{l}\text { as } \Delta F / F_{\mathrm{m}}{ }^{\prime} \\
\text { naximum quantum yield } \\
\text { ffective quantum yield }\end{array}$ \\
\hline
\end{tabular}

Baker \& Oxborough 2005, Consalvey et al. 2005). Similarly, the effective photochemical efficiency of PSII photochemistry (or effective quantum yield) at any given actinic irradiance is determined as $\left(F_{\mathrm{m}}{ }^{\prime}-F^{\prime}\right) / F_{\mathrm{m}}{ }^{\prime}$, and termed $F_{\mathrm{q}}{ }^{\prime} / F_{\mathrm{m}}{ }^{\prime}$.

For this investigation, the Diving-PAM was set to deliver red pulse modulated light at $655 \mathrm{~nm}$ followed by steps of actinic light every $20 \mathrm{~s}$. Ralph et al. (1999) previously employed light steps of $10 \mathrm{~s}$ duration for RLCs. However, Perkins et al. (2006) found that in high light acclimated diatoms, $10 \mathrm{~s}$ irradiance steps were not sufficient for an accurate determination of fluorescence parameters as a result of rapid induction of fluorescence quenching compared to the comparatively slow data acquisition time of the PAM. This issue is instrument specific and not microalgae specific; therefore, $20 \mathrm{~s}$ irradiance steps were used in this investigation, which are still essentially 'rapid'. Whilst this approach may not be directly comparable with that used for other coral studies (e.g. Ralph et al. 1999), our approach remains valid for comparisons between species and environments considered here. Other key Diving-PAM settings were: actinic light factor $=0.5$, light curve intensity $=5$, saturation width $=0.8$, saturation intensity $=3$, gain $=2$ and signal damping $=2$.

Initial fluorescence measurements were collected in the absence of actinic light after a 5 to $10 \mathrm{~s}$ period of quasidarkness (Ralph \& Gademann 2005). This was followed by an increasing series of actinic light steps from 1 to $2350 \mu \mathrm{mol}$ photons $\mathrm{m}^{-2} \mathrm{~s}^{-1}$ delivered from an $8 \mathrm{~V}$ halogen bulb within the Diving-PAM via the fibre optic cable. Each actinic irradiance level was delivered for $20 \mathrm{~s}$ and the entire light gradient was performed over a period of $160 \mathrm{~s}$. The fibre optic probe was always placed on the uppermost coral surface parallel to the water surface.

Experimental procedure. PAM fluorometry was performed on 5 separate colonies of Porites lutea at each depth of 5,9 and $13 \mathrm{~m}( \pm 1 \mathrm{~m}$, as a result of tidal variation) at Sites 1 and 2 and additionally at $17 \mathrm{~m}$ at Site 2 from July to September 2004 (maximum depth at Site 1 was $13 \mathrm{~m}$ ). PAM fluorometry was also performed on 5 colonies of Diploastrea heliopora, Favia speciosa, $F$. matthaii and $P$. lutea at each site within the permanent quadrats at 8 to $10 \mathrm{~m}$ from July to September 2006. All data were collected on 50 min dives 
beginning at 09:00 h. Since the objectives of this investigation were to compare patterns of photoacclimation for (1) P. lutea between depths and sites, and (2) between species at one depth, the 2 datasets were therefore compared independently.

Characterizing photoacclimation. Each RLC provided a light-response of effective photochemical efficiency, $F_{\mathrm{q}}{ }^{\prime} / F_{\mathrm{m}}{ }^{\prime}$ (Fig. 2), that was then fitted to the following model describing the light-dependent nature of the quantum efficiency of PSII photochemistry (Suggett et al. 2003, Moore et al. 2005, Suggett et al. 2007) using least squares non-linear regression:

$$
F_{\mathrm{q}}{ }^{\prime} / F_{\mathrm{m}}{ }^{\prime}=\left[\left(F_{\mathrm{q}}{ }^{\prime} / F_{\mathrm{m}}{ }^{\prime}(\max ) \mathrm{E}_{\mathrm{k}}\right)\left(1-\exp \left(-\mathrm{E} / \mathrm{E}_{\mathrm{k}}\right)\right)\right] / \mathrm{E}
$$

where the term $E_{k}\left(\mu m o l\right.$ photons $\mathrm{m}^{-2} \mathrm{~s}^{-1}$ ) is the light saturation parameter and describes the transition be-
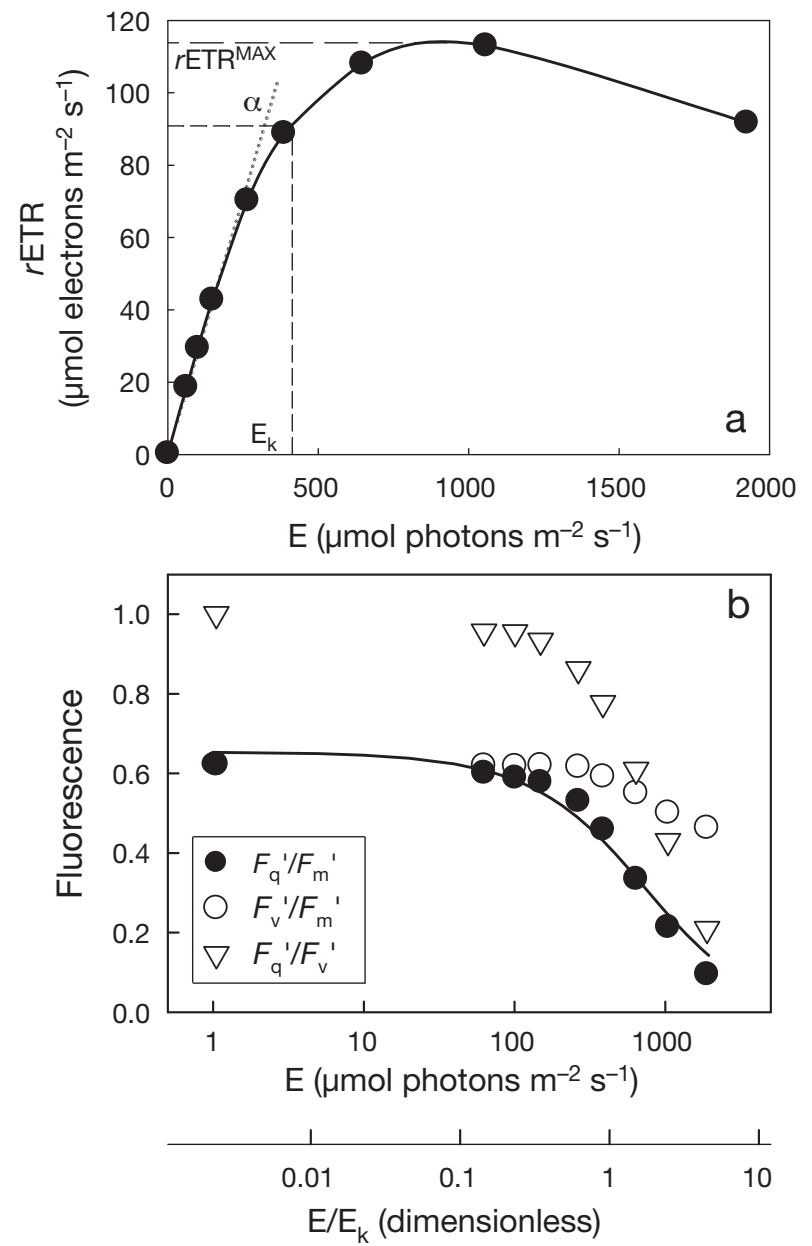

Fig. 2. Porites lutea. Examples of (a) relative electron transport ( $r$ ETR) and (b) fluorescence light-response (E, $\mu \mathrm{mol}$ photons $\mathrm{m}^{-2} \mathrm{~s}^{-1}$ ) curves generated from the Diving-PAM protocol. For (a), light-dependent ( $\alpha$, dimensionless) and lightsaturated $r$ ETR $\left(r\right.$ ETR $^{\text {max }}$, $\mu$ mol electron $\left.\mathrm{m}^{-2} \mathrm{~s}^{-1}\right)$ are described using Eq. (3). $\mathrm{E}_{\mathrm{k}}$ ( $\mu \mathrm{mol}$ photons $\mathrm{m}^{-2} \mathrm{~s}^{-1}$ ) describes the transition between light-limited and saturated photochemistry. Each fluorescence light response curve in (b) is plotted versus $\mathrm{E}$ or $\mathrm{E} / \mathrm{E}_{\mathrm{k}}$ (dimensionless) tween light-limited and light-saturated photochemical efficiency. Eq. (1) also conveniently yields an estimate of the maximum PSII photochemical efficiency (Moore et al. 2005, Suggett et al. 2007), termed here as $F_{\mathrm{q}}{ }^{\prime} / F_{\mathrm{m}}{ }^{\prime}(\max )$ (dimensionless) to avoid confusion with the measured maximum PSII photochemical efficiency, $F_{\mathrm{v}} / F_{\mathrm{m}}$, under dark-adapted conditions.

Fully dark-adapted measurements of $F_{\mathrm{v}} / F_{\mathrm{m}}$ are often difficult on corals in situ due to logistical and practical problems of night-time sampling (see Ralph et al. 1999). However, a period of 5 to $10 \mathrm{~s}$ of quasi-darkness when the Diving-PAM coral surface holder was attached allowed the rapid reoxidation of electron acceptor $Q_{\mathrm{A}}$. This period of quasi-darkness is often the best method to estimate $F_{0}$ and $F_{\mathrm{m}}$ in the field where longer dark-adaptation is not an option (Ralph \& Gademann 2005). Under these circumstances, derived values of $\left.F_{\mathrm{q}}{ }^{\prime} / F_{\mathrm{m}}^{\prime}{ }^{\prime} \max \right)$ using Eq. (1) following quasidarkness provided a convenient proxy for $F_{\mathrm{v}} / F_{\mathrm{m}}$.

Light driven changes of the effective photochemical efficiency, $F_{\mathrm{q}}{ }^{\prime} / F_{\mathrm{m}}{ }^{\prime}$, describes the operation of various photochemical and non-photochemical mechanisms for dissipating absorbed excitation energy (Suggett et al. 2003). Under relatively low actinic irradiances, where $\mathrm{E}$ is typically $<\mathrm{E}_{\mathrm{k}}$, decreases of $F_{\mathrm{q}}{ }^{\prime} / F_{\mathrm{m}}$ ' are almost entirely the result of photochemistry and the utilisation of electron transport products downstream of PSII. Under relatively high actinic irradiances, $E$ is typically $>\mathrm{E}_{\mathrm{k}}$, and decreases of $F_{\mathrm{q}}{ }^{\prime} / F_{\mathrm{m}}{ }^{\prime}$ reflect the activation of additional non-photochemical processes that dissipate absorbed excitation energy as heat. Values of the photochemical operating efficiency of PSII reaction centres, $\left[F_{\mathrm{q}}{ }^{\prime} / F_{\mathrm{v}}{ }^{\prime}{ }^{\prime}=\left(F_{\mathrm{m}}{ }^{\prime}-F^{\prime}\right) /\left(F_{\mathrm{m}}{ }^{\prime}-F_{0}{ }^{\prime}\right)\right.$, dimensionless] and quantum efficiency of exciton transfer to PSII reaction centres under actinic light $\left[F_{\mathrm{v}}{ }^{\prime} / F_{\mathrm{m}}{ }^{\prime}=\left(F_{\mathrm{m}}{ }^{\prime}-F_{0}{ }^{\prime}\right) / F_{\mathrm{m}}{ }^{\prime}\right.$, dimensionless $]$ describe the photochemical and non-photochemical components of quenching and are otherwise known by the terms qP and qN respectively (Kromkamp \& Forster 2003, Suggett et al. 2003). However, these parameters simply describe the decrease in the photochemical operating efficiency of PSII and the efficiency of exciton energy transfer to PSII under actinic light as a result of the quenching mechanisms. Decreases in the photochemical operating efficiency, $\mathrm{qP}$, are mostly driven by changes in $F_{\mathrm{q}}{ }^{\prime}$, which decreases with the increased closure of PSII reaction centres and thus represents fluorescence quenched by photochemistry. Decreases in $\mathrm{qN}$ are mostly driven by changes in $F_{\mathrm{m}}{ }^{\prime}$, and initial values can indicate the 'poise' or potential of nonphotochemical quenching. The preferred method to assess non-photochemical quenching is $\left(F_{\mathrm{m}}-F_{\mathrm{m}}{ }^{\prime}\right) / F_{\mathrm{m}}{ }^{\prime}$ (denoted by NPQ in Table 1) (Ralph \& Gademann 2005). However, values of the derived maximum photochemical efficiency, $F_{\mathrm{q}}{ }^{\prime} / F_{\mathrm{m}}{ }^{\prime}(\max )$ (Eq. 1), can also be used 
as an indicator for the extent or 'poise' of non-photochemical quenching driven by photoacclimation since it is the product of $\mathrm{qN}$ and $\mathrm{qP}$, and corresponds with initial values of $F_{\mathrm{v}}{ }^{\prime} / F_{\mathrm{m}}{ }^{\prime}$ (qN) (Fig. 2).

Using values of $F_{\mathrm{q}}{ }^{\prime} / F_{\mathrm{m}}{ }^{\prime}$, a relative electron transport rate $\left(r\right.$ ETR, $\mu \mathrm{mol}$ electrons $\left.\mathrm{m}^{-2} \mathrm{~s}^{-1}\right)$ was calculated for each actinic light intensity (E) of the RLC:

$$
r \mathrm{ETR}=\frac{F_{\mathrm{q}}{ }^{\prime} / F_{\mathrm{m}}{ }^{\prime}}{2} \times \mathrm{E}
$$

To be consistent with previous studies the factor 2 was used, for the assumption that photons are divided equally between PSI and PSII (Consalvey et al. 2005) and that the quantum yield of electron transfer of a trapped photon within a reaction centre is 1 (Kromkamp \& Forster 2003). The light-dependent nature of electron transport was determined for each RLC by fitting values of $r$ ETR to E using a modified Jassby \& Platt (1976) model via least squares non-linear regression:

$$
r \mathrm{ETR}=r \mathrm{ETR}^{\mathrm{MAX}} \times\left[1-\exp \left(-\alpha \times \mathrm{E} / r \mathrm{ETR}^{\mathrm{MAX}}\right)\right]
$$

where the terms $\alpha$ (dimensionless) and $r \mathrm{ETR}^{\mathrm{MAX}}$ ( $\mu \mathrm{mol}$ electrons $\mathrm{m}^{-2} \mathrm{~s}^{-1}$ ) describe the light-dependent and light-saturated $r$ ETR.

One of the main drawbacks of describing photoacclimation using effective photochemical efficiency $F_{\mathrm{q}}{ }^{\prime} / F_{\mathrm{m}}{ }^{\prime}$ (and other quenching parameters) or $r$ ETR is that the useable proportion of light which can be absorbed and used for photosynthesis, i.e. PUR, can differ hugely between species and environments (see MacIntyre et al. 2002, Suggett et al. 2007). In particular, corals can be subjected to light intensities of very different spectral quality with depth and site (Falkowski et al. 1990), whilst the light received by the zooxanthellae can also be modified by both the pigmentation of the host and zooxanthellae (Stambler \& Dubinsky 2005) and corallite skeletal architecture (Enriquez et al. 2005). Since this investigation did not measure the absorption spectrum of corals and Symbiodinium (to calculate PUR), values of $F_{\mathrm{q}}{ }^{\prime} / F_{\mathrm{m}}{ }^{\prime}, F_{\mathrm{q}}{ }^{\prime} / F_{\mathrm{v}}{ }^{\prime}$, $F_{\mathrm{v}}{ }^{\prime} / F_{\mathrm{m}}{ }^{\prime}$ and $r$ ETR were plotted against light intensity expressed relative to saturating light intensity, i.e. $E / E_{k}$, rather than against $E$ (see Fig. 2). In this way, trends of photoacclimation are expressed independently of how PUR may differ between locales and species, and reflects whether mechanisms associated with regulating light-limited (below $\mathrm{E}_{\mathrm{k}}$ ) or light-saturated (above $\mathrm{E}_{\mathrm{k}}$ ) photosynthesis are preferentially modified to optimise towards $\mathrm{E}_{\mathrm{k}}$. The term $\mathrm{E}_{\mathrm{K}}$ is conventionally derived from $r \mathrm{ETR}^{\mathrm{MAX}} / \alpha$. However, $r \mathrm{ETR}$ is derived from measurements of $F_{\mathrm{q}}{ }^{\prime} / F_{\mathrm{m}}{ }^{\prime}$; therefore, values of $\mathrm{E}_{\mathrm{k}}$ here are calculated from Eq. (1) since it describes the dependence of $F_{\mathrm{q}}{ }^{\prime} / F_{\mathrm{m}}$ ' upon $\mathrm{E}$ to yield a direct measure of $\mathrm{E}_{\mathrm{K}}$.

\section{RESULTS}

\section{Growth and distribution}

Of the massive species investigated, Porites lutea and Diploastrea heliopora were the most abundant at Sites 1 (relatively turbid) and 2 (low-turbidity) respectively (Table 2). Dominance by $P$. lutea at Site 1 was particularly pronounced $(32 \%$ of the total massive population within the quadrats). Favia speciosa was the least abundant species at both sites. The percentage of live coral cover was significantly higher at Site 2 $(50.0 \pm 3.01 \%)$ compared to Site $1\left(31.7 \pm 5.29 \%\right.$; $t_{4}=$ 2.77, p < 0.05). Most coral colonies were encrusting (49\% of total coral colonies present) or massive $(25 \%)$ at Site 2. In contrast, massive corals accounted for the majority of colonies found at Site 1 (71\%) with encrusting corals accounting for only $16 \%$.

Growth data had high intraspecific variability between colonies ranging from zero growth to ca. $80 \mathrm{~cm}^{2}$ in a year, making most interspecific comparisons non-significant. When comparing growth rates between sites, the only species to increase significantly from the relatively turbid to the low-turbidity site was Favia matthaii $(t=-2.36, \mathrm{p}<0.05, \mathrm{n}=11)$ (Table 3).

Table 2. Diploastrea heliopora, Favia matthaii, Favia speciosa and Porites lutea. Mean \pm SE percentage of coral cover and number of coral colonies for quadrats $(\mathrm{n}=3)$ from Sites 1 and 2 , in addition to size range of corals $\left(\mathrm{m}^{2}\right)$ and growth $\left(\mathrm{cm} \mathrm{yr}^{-1}\right)$. Data presented are for total live hard coral present within the quadrats and the 4 massive coral species expressed relative to the total

\begin{tabular}{|c|c|c|c|c|c|c|c|c|}
\hline \multirow[t]{2}{*}{ Species } & \multicolumn{2}{|c|}{$\begin{array}{c}\% \text { cover }- \\
(\text { Mean } \pm \mathrm{SE})\end{array}$} & \multicolumn{2}{|c|}{$\begin{array}{l}\text { No. colonies } \\
(\text { Mean } \pm \mathrm{SE})\end{array}$} & \multicolumn{2}{|c|}{$\begin{array}{c}\text { Coral size range - } \\
\left(\mathrm{m}^{2}, \min -\max \right)\end{array}$} & \multicolumn{2}{|c|}{$\begin{array}{l}\text { Growth - } \\
\left(\mathrm{cm}^{2} \mathrm{yr}^{-1}\right)\end{array}$} \\
\hline & Site 1 & Site 2 & Site 1 & Site 2 & Site 1 & Site 2 & Site 1 & Site 2 \\
\hline Total live coral & $31.7 \pm 7.90$ & $50.0 \pm 3.01$ & $48.0 \pm 27.7$ & $26.3 \pm 15.2$ & - & - & - & - \\
\hline P. lutea & $30.6 \pm 17.6$ & $8.85 \pm 5.11$ & $15.7 \pm 9.05$ & $2.67 \pm 1.54$ & $0.13-1.18$ & $0.17-1.60$ & $18.4 \pm 5.01$ & $6.44 \pm 2.65$ \\
\hline D. heliopora & $4.45 \pm 2.57$ & $15.7 \pm 9.07$ & $2.00 \pm 1.15$ & $4.33 \pm 2.50$ & $0.01-1.13$ & $0.57-1.38$ & $11.2 \pm 5.01$ & $26.6 \pm 11.7$ \\
\hline F. matthaii & $18.2 \pm 10.5$ & $11.0 \pm 6.37$ & $8.00 \pm 4.62$ & $2.67 \pm 1.54$ & $0.02-0.36$ & $0.17-1.04$ & $5.53 \pm 2.73$ & $38.5 \pm 11.8$ \\
\hline F. speciosa & $4.35 \pm 2.51$ & $5.13 \pm 2.96$ & $2.00 \pm 1.15$ & $1.00 \pm 0.58$ & $0.32-0.73$ & $0.16-1.09$ & $0.96 \pm 0.47$ & $2.79 \pm 1.81$ \\
\hline
\end{tabular}
live hard coral present 
Table 3. Diploastrea heliopora, Favia matthaii, Porites lutea and Favia speciosa. Mean $\pm \mathrm{SE}(\mathrm{n}=5)$ values of $\alpha$ (dimensionless), $r \mathrm{ETR}^{\mathrm{MAX}}\left(\mu \mathrm{mol}\right.$ electrons $\left.\mathrm{m}^{-2} \mathrm{~s}^{-1}\right)$, $F_{\mathrm{q}}{ }^{\prime} / F_{\mathrm{m}}{ }^{\prime}(\max )$ (dimensionless) and $\mathrm{E}_{\mathrm{k}}\left(\mu \mathrm{mol}\right.$ photons $\mathrm{m}^{-2} \mathrm{~s}^{-1}$ ) at permanent quadrats at Sites 1 and 2 at $10 \mathrm{~m}$. Values of $\mathrm{E}_{\mathrm{k}}$ were derived using Eq. (1) and not as $r \mathrm{ETR}^{\mathrm{MAX}} / \alpha$. Data were compared between species at each site using ANOVA and subsequent Tukey's test; significantly different values $(p<0.05)$ are indicated as groupings using different letter superscripts

\begin{tabular}{|lcccc|}
\hline Species & $\alpha$ & $r \mathrm{ETR}^{\mathrm{MAX}}$ & $F_{\mathrm{q}}{ }^{\prime} / F_{\mathrm{m}}{ }^{\prime}(\max )$ & $\mathrm{E}_{\mathrm{k}}$ \\
\hline Site 1 & & & & \\
Porites lutea & $0.44 \pm 0.01^{\mathrm{a}}$ & $94 \pm 12^{\mathrm{a}}$ & $0.70 \pm 0.01^{\mathrm{a}}$ & $342 \pm 48^{\mathrm{a}}$ \\
Diploastrea heliopora & $0.44 \pm 0.02^{\mathrm{a}}$ & $88 \pm 7^{\mathrm{a}}$ & $0.72 \pm 0.01^{\mathrm{a}, \mathrm{b}}$ & $298 \pm 22^{\mathrm{a}}$ \\
Favia matthaii & $0.43 \pm 0.01^{\mathrm{a}}$ & $94 \pm 7^{\mathrm{a}}$ & $0.71 \pm 0.01^{\mathrm{a}, \mathrm{b}}$ & $317 \pm 26^{\mathrm{a}}$ \\
Favia speciosa & $0.48 \pm 0.01^{\mathrm{a}}$ & $66 \pm 5^{\mathrm{a}}$ & $0.74 \pm 0.00^{\mathrm{b}}$ & $227 \pm 19^{\mathrm{a}}$ \\
$F_{3,16}$ & 1.85 & 2.64 & 3.86 & 2.5 \\
Site 2 & & & & \\
Porites lutea & $0.43 \pm 0.01^{\mathrm{a}}$ & $107 \pm 7^{\mathrm{a}}$ & $0.65 \pm 0.01^{\mathrm{a}}$ & $431 \pm 29^{\mathrm{a}}$ \\
Diploastrea heliopora & $0.43 \pm 0.01^{\mathrm{a}}$ & $103 \pm 4^{\mathrm{a}}$ & $0.66 \pm 0.01^{\mathrm{a}}$ & $397 \pm 14^{\mathrm{a}, \mathrm{b}}$ \\
Favia matthaii & $0.43 \pm 0.01^{\mathrm{a}}$ & $92 \pm 6^{\mathrm{a}}$ & $0.71 \pm 0.01^{\mathrm{b}}$ & $312 \pm 24^{\mathrm{b}, \mathrm{c}}$ \\
Favia speciosa & $0.47 \pm 0.01^{\mathrm{b}}$ & $85 \pm 7^{\mathrm{a}}$ & $0.73 \pm 0.01^{\mathrm{b}}$ & $296 \pm 24^{\mathrm{c}}$ \\
$F_{3,16}$ & 5.51 & 2.54 & 14.58 & 7.85 \\
\hline
\end{tabular}

single negative correlation when plotted against optical depth (Pearson product-moment correlation, $\mathrm{r}=-0.738$ and $-0.703, \mathrm{n}=35, \mathrm{p}<0.001$ respectively) (Fig. 3b,d). Values for the light-limited coefficient for PSII photochemistry $(\alpha)$ and derived maximum PSII photochemical efficiency $\left(F_{\mathrm{q}}^{\prime} / F_{\mathrm{m}}{ }^{\prime}(\max )\right)$ increased with depth and exhibited a single positive relationship with optical depth $(r=0.686$ and $0.719, \mathrm{n}=35, \mathrm{p}<0.001$ respectively) (Fig. 3a,c).

Values of $r$ ETR were plotted against $\mathrm{E} / \mathrm{E}_{\mathrm{k}}$ (Fig. 4a,d) and decreased with increasing depth for both sites. In order to account for differences observed between depths and, hence, different light regimes, values for $\mathrm{qP}$ and NPQ were also plotted against $\mathrm{E} / \mathrm{E}_{\mathrm{k}}$ (Fig. 4). At both sites, the light-

\section{Photoacclimation of Porites lutea}

As expected, values for the light saturation coefficient $\left(E_{k}\right)$ and maximum electron transport rate $\left(r \mathrm{ETR}^{\mathrm{MAX}}\right)$ decreased with depth at both Sites 1 and 2 (data not shown). Both $\mathrm{E}_{\mathrm{k}}$ and $r \mathrm{ETR}^{\mathrm{MAX}}$ followed a
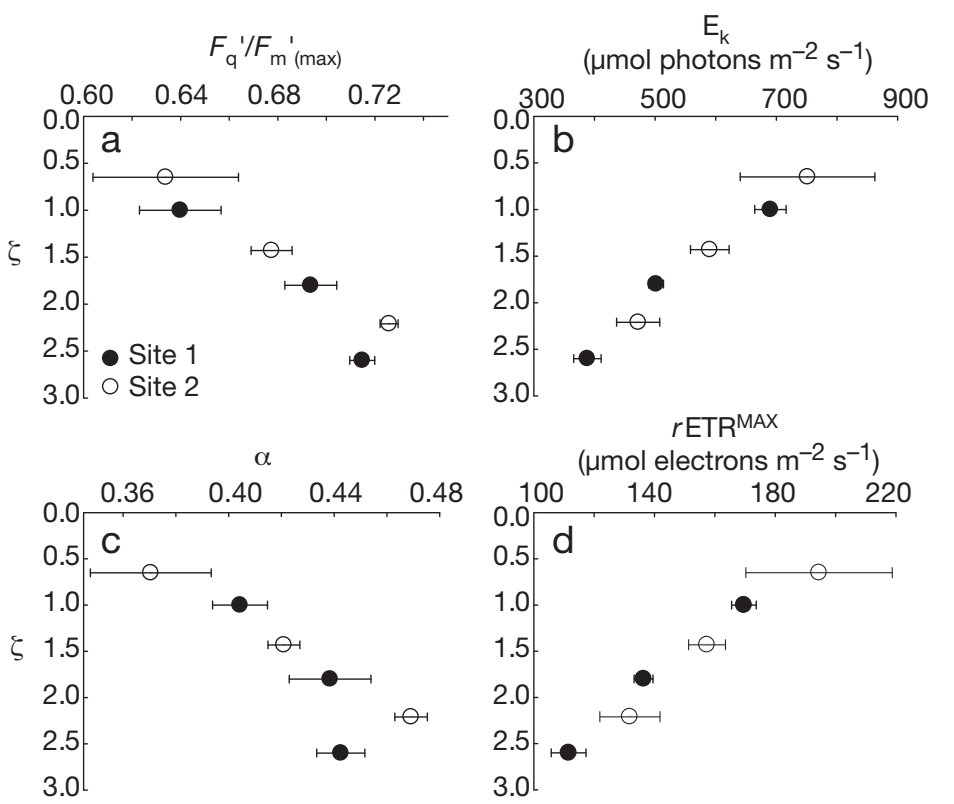

Fig. 3. Porites lutea. Mean \pm SE $(n=5)$ values of (a) derived maximum photochemical efficiency of PSII $\left(F_{\mathrm{q}}{ }^{\prime} / F_{\mathrm{m}}{ }^{\prime}(\max )\right.$, dimensionless), (b) light saturation coefficient $\left(E_{\mathrm{k}}, \mu \mathrm{mol}\right.$ photons $\left.\mathrm{m}^{-2} \mathrm{~s}^{-1}\right)$, (c) light-limited initial slope of a light response curve $(\alpha$, dimensionless) and (d) lightsaturated electron transport $\left(r \mathrm{ETR}^{\mathrm{MAX}}, \mu \mathrm{mol}\right.$ electrons $\left.\mathrm{m}^{-2} \mathrm{~s}^{-1}\right)$ from Sites 1 and 2 plotted versus optical depth. $\zeta=K_{d(\mathrm{PAR})} \times$ depth (dimensionless). Error bars are omitted from optical depth data, as mean site $K_{d(\mathrm{PAR})}$ were used to calculate optical depth over the experimental period response curves of $\mathrm{qP}$ were constant for all depths, whereas NPQ trends followed those of $r$ ETR, such that NPQ increased with decreased depth and did not exhibit similar light-response curves relative to $\mathrm{E} / \mathrm{E}_{\mathrm{k}}$.

\section{Photoacclimation between massive species}

Photoacclimation between species followed the same trend established for Porites lutea, since light-response curves for qP but not NPQ were similar when plotted against E/ $\mathrm{E}_{\mathrm{k}}$ (Fig. 5). However, despite these differences of NPQ, values of $r \mathrm{ETR}^{\mathrm{MAX}}$ were not different between species (Table 3). In contrast to $r \mathrm{ETR}^{\mathrm{MAX}}$, values for $\alpha, F_{\mathrm{q}}{ }^{\prime} / F_{\mathrm{m}}^{\prime}{ }^{\prime}(\max )$ and $\mathrm{E}_{\mathrm{k}}$ differed between species (Table 3). Values of both $\alpha$ and $E_{\mathrm{k}}$ only differed between species at Site 2 . Values of $F_{\mathrm{q}}{ }^{\prime} / F_{\mathrm{m}}{ }^{\prime}$ (max) differed between species at both sites with $P$. lutea and Favia speciosa lowest and highest, respectively. The trend of $P$. lutea and F. speciosa having highest or lowest data values was also observed in other fluorescence variables, with Diploastrea heliopora and F. matthaii intermediates. Both $F_{\mathrm{q}}{ }^{\prime} / F_{\mathrm{m}}{ }^{\prime}(\max )$ and $\mathrm{E}_{\mathrm{k}}$ are indicative of the state of photoacclimation. Since the derived maximum photochemical efficiency $F_{\mathrm{q}}{ }^{\prime} / F_{\mathrm{m}}{ }^{\prime}(\max )$, is comprised of both $\mathrm{qP}\left(F_{\mathrm{q}}{ }^{\prime} / F_{\mathrm{v}}{ }^{\prime}\right)$ and qN $\left(F_{\mathrm{v}}{ }^{\prime} / F_{\mathrm{m}}{ }^{\prime}\right)$ components (see 'Materials and methods', Fig. 2), $F_{\mathrm{q}}{ }^{\prime} / F_{\mathrm{m}}{ }^{\prime}(\max )$ can be used with care to describe the 'poise' or potential of nonphotochemical quenching driven by photoacclimation. Since $F_{\mathrm{q}}{ }^{\prime} / F_{\mathrm{m}}{ }^{\prime}(\max )$ corresponded well with initial qN for all species (data not shown), 


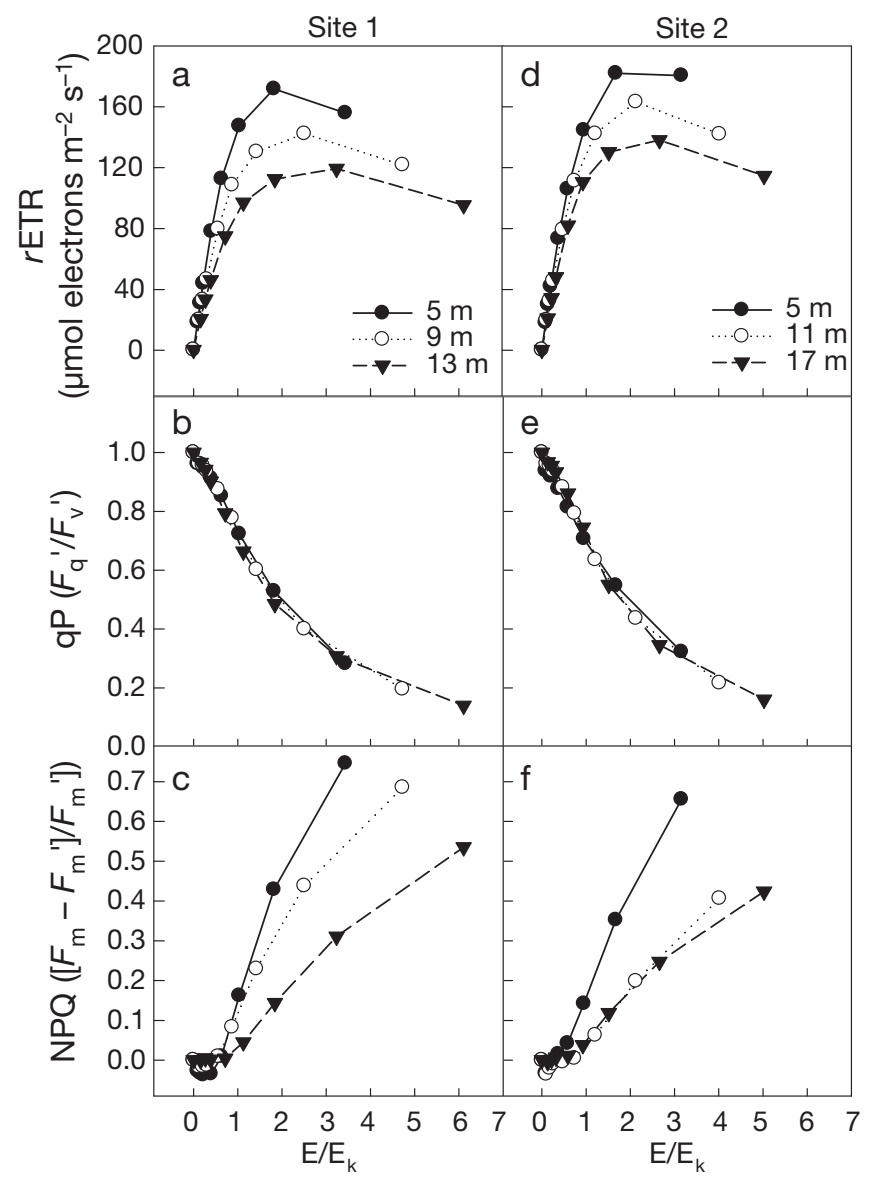

Fig. 4. Porites lutea. Light response of $(\mathrm{a}, \mathrm{d}) \mathrm{rETR}(\mu \mathrm{mol}$ electrons $\left.\mathrm{m}^{-2} \mathrm{~s}^{-1}\right)$, (b,e) photochemical quenching (qP), $\left(F_{\mathrm{q}}{ }^{\prime} / F_{\mathrm{v}}{ }^{\prime}\right.$, dimensionless) and $(\mathrm{c}, \mathrm{f})$ non-photochemical quenching (NPQ), $\left(F_{\mathrm{m}}-F_{\mathrm{m}}{ }^{\prime}\right) / F_{\mathrm{m}}{ }^{\prime}$, (dimensionless) at Sites 1 and 2. Each light response is determined from the mean $(\mathrm{n}=5)$ of 5 RLCs from separate colonies; SE bars have been omitted for clarity. Light $\left(E, \mu m o l\right.$ photons $\left.\mathrm{m}^{-2} \mathrm{~s}^{-1}\right)$ is plotted relative to $\mathrm{E}_{\mathrm{k}}\left(\mathrm{E} / \mathrm{E}_{\mathrm{k}}\right.$, dimensionless $)$

species which had lower (relative) $F_{\mathrm{q}}{ }^{\prime} / F_{\mathrm{m}}{ }^{\prime}(\max )$, thus had increased initial non-photochemical quenching. When $F_{\mathrm{q}}{ }^{\prime} / F_{\mathrm{m}}{ }^{\prime}(\max )$ was compared to the light saturation coefficient $E_{k}$ from all species at both sites, which indicates the capacity of an organism for photosynthesis before it is light saturated, values co-varied (Pearson productmoment correlation, $\mathrm{r}=-0.972, \mathrm{n}=40, \mathrm{p}<0.001$ ) (Fig. 6).

\section{DISCUSSION}

\section{Growth and distribution of massive coral species}

Coral growth data did not correspond well with coral distribution and abundance or with photoacclimatory ability at the 2 sites. Previous research on Porites lutea growth rates (Crabbe \& Smith 2005) found increased

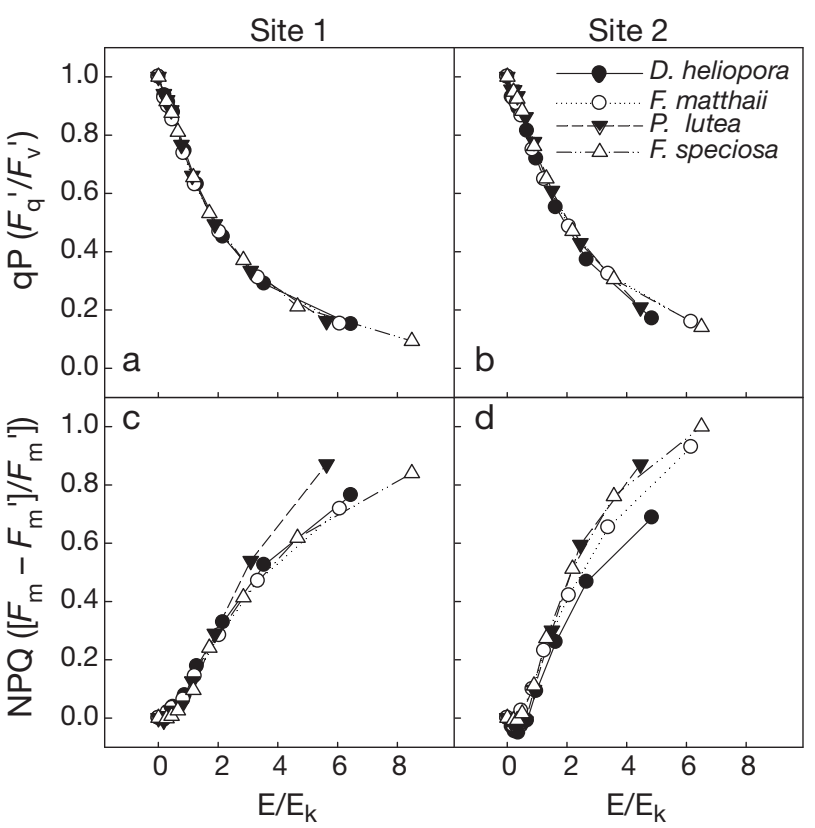

Fig. 5. Diploastrea heliopora, Favia matthaii, Porites lutea and F. speciosa. Mean $(\mathrm{n}=5)$ values of qP at (a) Site 1 and (b) Site 2, and NPQ at (c) Site 1 and (d) Site 2 of colonies at $10 \mathrm{~m}$. All values are plotted against light normalised to mean depth $E_{k}\left(E / E_{k}\right) . S E$ is omitted for clarity

growth at Site 2 relative to Site 1 . However, since massive corals may not grow in a uniform way under different environments due to differing light properties (Rosenfeld et al. 2003), dimension-based measurements of growth can be problematic, especially in massive corals species such as $P$. lutea, where linear growth may be ca. $5 \mathrm{~mm} \mathrm{yr}^{-1}$ (Rosenfeld et al. 2003, Crabbe \& Smith 2005). Other coral species (branching and massive) were found to double growth rates from Site 1 to Site 2 (Crabbe \& Smith 2002, 2005), but in this investigation an increase in growth was only observed

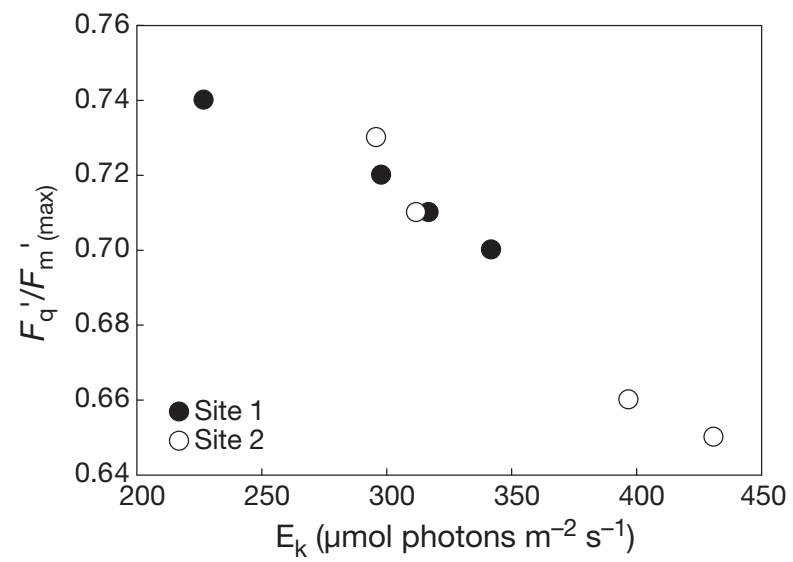

Fig. 6. Diploastrea heliopora, Favia matthaii, Porites lutea and $F$. speciosa. Mean $(\mathrm{n}=5) F_{\mathrm{q}}{ }^{\prime} / F_{\mathrm{m}}{ }^{\prime}{ }_{\max }$ (dimensionless) of colonies from Sites 1 and 2 plotted against $E_{k}$ 
in Favia matthaii. Photosynthetically-derived energy is not used exclusively for growth; a large percentage is used for mucus production (Crossland et al. 1980, Muscatine et al. 1984), and some may also contribute to cell maintenance or reproduction (Dubinsky \& Berman-Frank 2001). As photoacclimation may not always meet the entire energy requirements of the coral, external nutrient input via heterotrophy may be essential for corals under low light conditions (Mass et al. 2007), and, dependent on the coral species, heterotrophy may be up-regulated under turbid conditions (Anthony 2000). It is currently unknown whether the high abundance of $P$. lutea is influenced by an increase in heterotrophically derived nutrients. However, other factors such as larval survival and dispersion over a wide range of environmental gradients also play a crucial role in coral distribution and abundance, but it is unknown how the species investigated here differ with regard to this.

\section{Depth and turbidity induced photoacclimation of massive coral species}

Porites lutea exhibited a pattern of photoacclimation in which both $\mathrm{E}_{\mathrm{k}}$ and $r \mathrm{ETR}^{\mathrm{MAX}}$ decreased with increased optical depth. This relationship between photophysiology and optical depth illustrates the organism's response to light availability, defined by depth or turbidity; patterns observed here were consistent with typical photoacclimation patterns of free-living microalgae and in hospite zooxanthellae (Perkins et al. 2006, Mass et al. 2007). When light was expressed relative to $E_{k}$, all light response curves of photochemical quenching for $P$. lutea were similar. Thus, photoacclimation $\left(E_{k}\right)$ acts so that the redox state of $\mathrm{qP}$ is maintained relative to the growth light E. Such an observation would be consistent with the concept that the redox state of PSII, specifically of electron acceptor plastoquinone, is used as a cue for photoacclimation (Escoubas et al. 1995).

Values of $\alpha$ and $F_{\mathrm{q}}{ }^{\prime} / F_{\mathrm{m}}{ }^{\prime}(\max )$ increased with optical depth to increase light harvesting under low light conditions (Perkins et al. 2006). Such modification occurs primarily by regulating the number of available reaction centres associated with PSII or by altering pigments utilised for light harvesting (Falkowski \& Raven 1997). This alters the effective absorption antennae size of PSII (Falkowski \& Dubinsky 1981, Gorbunov et al. 2001, Lesser \& Gorbunov 2001). When plotted against $E / E_{k}$, shallow corals also had higher values of NPQ and lower initial values of $\mathrm{qN}\left(F_{\mathrm{v}}{ }^{\prime} / F_{\mathrm{m}}{ }^{\prime}\right.$, data not shown), indicating an increased investment of non-photochemical quenching mechanisms relative to deeper corals. Here, photoacclimation acts to protect the reaction centres from excess excitation (Ralph \& Gademann 2005), for example, alterations of the antennae pigment system to reduce the transfer efficiency of excitation energy into the PSII reaction centres (Brown et al. 2000). Once $E / E_{k}>1$ (in the light saturated region of the curve), mechanisms are activated to enhance non-photochemical quenching and reduce potential damage to PSII reaction centres, such as xanthophyll cycling (Warner \& Berry-Lowe 2006) and PSII reaction centre deactivation (Gorbunov et al. 2001). However, $E_{k}$ in this investigation was determined from RLCs and therefore was not necessarily the same as would be expected from steady state fluorometry.

As with the majority of previous Diving-PAM-based coral investigations, one of the major limitations to assessing RLCs was that no differences in absorption between coral colonies or species were accounted for; consequently, rETR curves were used instead of ETR curves, as well as certain data manipulations $\left(E / E_{k}\right)$. However, large variability in photosynthetic pigment concentrations (1.5- to 10-fold), which would directly affect light absorption, have been observed for Porites lutea colonies across a depth range of 2 to $20 \mathrm{~m}$ (Apprill et al. 2007). Pigment concentrations can also vary according to light availability, although ratios of pigments appear to remain relatively constant (Falkowski \& Dubinsky 1981, Dustan 1982, Titlyanov et al. 2001, Stambler \& Dubinsky 2005). Other investigations that have used respirometers to determine photosynthetic parameters (Dubinsky et al. 1984, Muscatine et al. 1984, Mass et al. 2007) show similar results to those described here; specifically decreased $P_{\max }$ and increased $\alpha$ deeper in the water column. The present investigation assumed that all coral colonies tested (within and between species) had a single zooxanthellae genetic type predominating throughout. However, differences in photosynthetic architecture are known to exist between zooxanthellae types (IglesiasPrieto \& Trench 1994, S. J. Hennige \& D. J. Suggett unpubl. data) and more than one Symbiodinium genotype often exists within a single coral colony (Warner et al. 2006, Apprill et al. 2007). In circumstances where the Symbiodinium assemblage may change in dominance over an experiment or between treatments, using fluorometric measurements such as $F_{\mathrm{v}} / F_{\mathrm{m}}$ alone may be inadequate to determine photoacclimation due to differences in biophysical signatures (Robison \& Warner 2006, S. J. Hennige \& D. J. Suggett unpubl. data). However, the data manipulations demonstrated here, where $\mathrm{qP}$ is expressed relative to $\mathrm{E} / \mathrm{E}_{\mathrm{k}}$, indicate that even if the Symbiodinium assemblage did change between treatments, qP would likely remain constant between Symbiodinium types due to modification of non-photochemical quenching. 
As with the observations for Porites lutea, absorption may be highly variable between coral species (Dustan 1982, Enriquez et al. 2005, Stambler \& Dubinsky 2005) and would dominate the changes in acclimation observed where corals are light-limited $\left(E / E_{k}<1\right)$. Even though our results do not account for any change in absorption between species or site, we do observe some consistent patterns associated with photoacclimation by expressing $E$ relative to $E_{k}$. Lower values of the derived maximum PSII photochemical efficiency, $F_{\mathrm{q}}{ }^{\prime} / F_{\mathrm{m}}{ }^{\prime}(\max )$ (which also indicate increased non-photochemical quenching), corresponded with higher values of saturating growth irradiance $\left(\mathrm{E}_{\mathrm{k}}\right)$, a pattern consistent with high light acclimation (Ralph \& Gademann 2005, Perkins et al. 2006). This correlation between lower efficiency and higher capacity for photosynthesis was observed for all species between sites; however, it is unclear from our data whether the same bathymetric patterns of photoacclimation observed for $P$. lutea would apply to all other massive species.

Distribution of all 4 coral species was not solely defined by photoacclimatory ability. All 4 species followed the same pattern with depth as observed for Porites lutea: that light-response curves of $\mathrm{qP}$ were similar relative to $E / E_{k}$, but that NPQ differed between species. It was also demonstrated that elevated NPQ under high growth light intensities corresponded with the maintenance of higher saturating growth irradiance. Also, values of the derived maximum photochemical efficiency $F_{\mathrm{q}}{ }^{\prime} / F_{\mathrm{m}}{ }^{\prime}(\max )$ and $\mathrm{E}_{\mathrm{k}}$ differed between species at the same depth. Such differences will be driven by non-photochemical quenching acclimation mechanisms that operate in both the antennae bed and reaction centre complexes, which alter the transfer efficiency of absorbed light into the reaction centres and, in turn, the photochemical efficiency that is achieved. However, identification of the exact mechanisms responsible here is not possible. Although these differences in non-photochemical quenching capacity did not directly correlate with species abundance and distribution, the least abundant species at both sites, Favia speciosa, did exhibit the lowest $\mathrm{E}_{\mathrm{k}}$ and highest $F_{\mathrm{q}}{ }^{\prime} / F_{\mathrm{m}}{ }^{\prime}$ (max). At present we cannot determine whether this is due to differences in photoacclimatory ability that result from changes in Symbiodinium type (adaptation) or are specific to this host. The role of the host in determining coral distribution thus needs to be quantified, since the differences observed in nonphotochemical quenching and $F_{\mathrm{q}}{ }^{\prime} / F_{\mathrm{m}}{ }^{\prime}(\max )$ between coral species may be further influenced by differences in host protective pigmentation (Salih et al. 2000) or skeletally enhanced light (Enriquez et al. 2005). Consequently, photosynthetic output may be partially constrained by host factors which will affect energetic investment in growth and reproduction.
In summary, all corals in this investigation were observed to modify the extent of NPQ to enable maintenance of a constant photochemical operating efficiency (qP). This same pattern was also observed for Porites lutea as it grew across a depth and site-driven light gradient. Certain fluorometric parameters used in this investigation to assess Symbiodinium photosynthetic efficiency and capacity (light saturation point) may be useful in determining coral distribution and abundance, but only if further work is performed that characterises the fluorescence signatures inherent to the different Symbiodinium genotypes that exist in nature. Despite well-published limitations associated with the use of RLCs, data manipulations demonstrated here highlight further applications of fluorescence techniques to assess photoacclimation. Ultimately, the observation that corals photoacclimate according to a single pattern, i.e. by maintaining photochemical operating efficiency (qP) relative to $\mathrm{E} / \mathrm{E}_{\mathrm{k}}$, suggests that for the growth conditions considered here, coral distribution is not constrained by the ability of corals to photoacclimate. Differences observed in coral abundance at each site must therefore be attributed to differences between coral hosts, meaning that while photoacclimatory ability facilitates coral distribution, variability between host coral species defines abundance and hence reef composition.

Acknowledgements. The authors thank R. Geider and 3 anonymous reviewers for comments and suggestions for improving the manuscript. This work was funded through a National Environmental Research Council (NERC) PhD studentship to S.J.H, a NERC fellowship to D.J.S. and by Operation Wallacea through collaboration with the Wakatobi Taman National. Also, thanks to the Wallacea Foundation, J. Jompa of the Centre of Coral Reef Studies, Hasanuddin University, and the Indonesian Institute of Sciences (LIPI research permit granted to D.J.S.).

\section{LITERATURE CITED}

Anthony KRN (2000) Enhanced particle-feeding capacity of corals on turbid reefs (Great Barrier Reef, Australia). Coral Reefs 19:59-67

Apprill AM, Bidigare RR, Gates RD (2007) Visibly healthy corals exhibit variable pigment concentrations and symbiont phenotypes. Coral Reefs 26:387-397

- Arias-Gonzalez JE, Delesalle B, Salvat B, Galzin R (1997) Trophic functioning of the Tiahura reef sector, Moorea Island, French Polynesia. Coral Reefs 16:231-246

Baker NR, Oxborough K (2005) Chlorophyll fluorescence as a probe of photosynthetic productivity. In: Papageorgiou GC, Govindjee (eds) Chlorophyll a fluorescence: a signature of photosynthesis. Advances in photosynthesis and respiration, Vol 19. Springer, The Netherlands, p 65-82

Brown BE, Dunne RP, Warner ME, Ambarsari I, Fitt WK, Gibb SW, Cummings DG (2000) Damage and recovery of photosystem II during a manipulative field experiment on solar bleaching in the coral Goniastrea aspera. Mar Ecol Prog Ser 195:117-124 
Consalvey M, Perkins RG, Paterson DM, Underwood GJC (2005) PAM fluorescence: a beginners guide for benthic diatomists. Diatom Res 20:1-22

Crabbe MJC, Smith DJ (2002) Comparison of two reef sites in the Wakatobi Marine National Park (SE Sulawesi, Indonesia) using digital image analysis. Coral Reefs 21:242-244

> Crabbe MJC, Smith DJ (2005) Sediment impacts on growth rates of Acropora and Porites corals from fringing reefs of Sulawesi, Indonesia. Coral Reefs 24:437-441

Crossland CJ, Barnes DJ, Borowitzka MA (1980) Diurnal lipid and mucus production in the staghorn coral Acropora acuminata. Mar Biol 60:81-90

Dubinsky Z, Berman-Frank I (2001) Uncoupling primary production from population growth in photosynthesizing organisms in aquatic ecosystems. Aquat Sci 63:4-17

Dubinsky Z, Falkowski PG, Porter JW, Muscatine L (1984) Absorption and utilization of radiant energy by lightadapted and shade-adapted colonies of the hermatypic coral Stylophora pistillata. Proc R Soc Lond B 222:203-214

Dustan P (1982) Depth-dependent photoadaptation by zooxanthellae of the reef coral Montastrea annularis. Mar Biol 68:253-264

English S, Wilkinson C, Baker V (1997) Survey manual for marine resources, Vol 1. Australian Institute of Marine Science, Townsville

Enriquez S, Mendez ER, Iglesias-Prieto R (2005) Multiple scattering on coral skeletons enhances light absorption by symbiotic algae. Limnol Oceanogr 50:1025-1032

Escoubas JM, Lomas M, LaRoche J, Falkowski PG (1995) Light intensity regulation of cab gene transcription is signaled by the redox state of the plastoquinone pool. Proc Natl Acad Sci USA 92:10237-10241

Falkowski PG, Dubinsky Z (1981) Light-shade adaptation of Stylophora pistillata, a hermatypic coral from the Gulf of Eilat. Nature 289:172-174

Falkowski PG, LaRoche J (1991) Acclimation to spectral irradiance in algae. J Phycol 27:8-14

Falkowski PG, Raven JA (1997) Aquatic photosynthesis, Vol 1. Blackwell Science, Oxford

Falkowski PG, Jokiel PL, Kinzie RA III (1990) Irradiance and corals. In: Dubinsky Z (ed) Coral reefs. Ecosystems of the world, Vol 25. Elsevier, Amsterdam, p 89-107

Gorbunov MY, Kolber ZS, Lesser MP, Falkowski PG (2001) Photosynthesis and photoprotection in symbiotic corals. Limnol Oceanogr 46:75-85

$>$ Hoegh-Guldberg O, Salvat B (1995) Periodic mass-bleaching and elevated sea temperatures: bleaching of outer reef slope communities in Moorea, French Polynesia. Mar Ecol Prog Ser 121:181-190

Holl M (1983) Zonation and diversity of scleractinia on reefs off SW Sulawesi, Indonesia. Drukkery Kanters BV, Alblasserdam

> Iglesias-Prieto R, Trench RK (1994) Acclimation and adaptation to irradiance in symbiotic dinoflagellates. 1. Responses of the photosynthetic unit to changes in photon flux density. Mar Ecol Prog Ser 113:163-175

Jassby AD, Platt T (1976) Mathematical formulation of relationship between photosynthesis and light for phytoplankton. Limnol Oceanogr 21:540-547

> Jones RJ, Hoegh-Guldberg O (2001) Diurnal changes in the photochemical efficiency of the symbiotic dinoflagellates (Dinophyceae) of corals: photoprotection, photoinactivation and the relationship to coral bleaching. Plant Cell Environ 24:89-99

Kenyon JC, Vroom PS, Page KN, Dunlap MJ, Wilkinson CB, Aeby GS (2006) Community structure of hermatypic corals at French frigate shoals, Northwestern Hawaiian Islands: capacity for resistance and resilience to selective stressors. Pac Sci 60:153-175

Kirk JTO (1994) Light \& photosynthesis in aquatic ecosystems, Vol 1. Cambridge University Press, Cambridge

Kromkamp JC, Forster RM (2003) The use of variable fluorescence measurements in aquatic ecosystems: differences between multiple and single turnover measuring protocols and suggested terminology. Eur J Phycol 38: 103-112

Lesser MP (2004) Experimental biology of coral reef ecosystems. J Exp Mar Biol Ecol 300:217-252

> Lesser MP, Gorbunov MY (2001) Diurnal and bathymetric changes in chlorophyll fluorescence yields of reef corals measured in situ with a fast repetition rate fluorometer. Mar Ecol Prog Ser 212:69-77

> Loya Y, Sakai K, Yamazato K, Nakano Y, Sambali H, van Woesik R (2001) Coral bleaching: the winners and the losers. Ecol Lett 4:122-131

MacIntyre HL, Kana TM, Anning T, Geider RJ (2002) Photoacclimation of photosynthesis irradiance response curves and photosynthetic pigments in microalgae and cyanobacteria. J Phycol 38:17-38

> Mass T, Einbinder S, Brokovich E, Shashar N, Vago R, Erez J, Dubinsky Z (2007) Photoacclimation of Stylophora pistillata to light extremes: metabolism and calcification. Mar Ecol Prog Ser 334:93-102

Moore CM, Lucas MI, Sanders R, Davidson R (2005) Basinscale variability of phytoplankton bio-optical characteristics in relation to bloom state and community structure in the Northeast Atlantic. Deep-Sea Res I 52:401-419

Muscatine L (ed) (1990) The role of symbiotic algae in carbon and energy flux in reef corals, Vol 25. Elsevier, Amsterdam

Muscatine L, Falkowski PG, Porter JW, Dubinsky Z (1984) Fate of photosynthetic fixed carbon in light-adapted and shade-adapted colonies of the symbiotic coral Stylophora pistillata. Proc R Soc Lond B 222:181-202

Perkins RG, Mouget JL, Lefebvre S, Lavaud J (2006) Light response curve methodology and possible implications in the application of chlorophyll fluorescence to benthic diatoms. Mar Biol 149:703-712

Ralph PJ, Gademann R (2005) Rapid light curves: a powerful tool to assess photosynthetic activity. Aquat Bot 82: 222-237

> Ralph PJ, Gademann R, Larkum AWD, Schreiber U (1999) In situ underwater measurements of photosynthetic activity of coral zooxanthellae and other reef-dwelling dinoflagellate endosymbionts. Mar Ecol Prog Ser 180:139-147

Robison JD, Warner ME (2006) Differential impacts of photoacclimation and thermal stress on the photobiology of four different phylotypes of Symbiodinium (Pyrrhophyta). J Phycol 42:568-579

> Rosenfeld M, Yam R, Shemesh A, Loya Y (2003) Implication of water depth on stable isotope composition and skeletal density banding patterns in a Porites lutea colony: results from a long-term translocation experiment. Coral Reefs $22: 337-345$

Salih A, Larkum A, Cox G, Kuhl M, Hoegh-Guldberg O (2000) Fluorescent pigments in corals are photoprotective. Nature 408:850-853

- Stambler N, Dubinsky Z (2005) Corals as light collectors: an integrating sphere approach. Coral Reefs 24:1-9

Suggett DJ, Oxborough K, Baker NR, MacIntyre HL, Kana TM, Geider RJ (2003) Fast repetition rate and pulse amplitude modulation chlorophyll a fluorescence measurements for assessment of photosynthetic electron transport in marine phytoplankton. Eur J Phycol 38:371-384 
Suggett DJ, Le Floc'H E, Harris GN, Leonardos N, Geider RJ (2007) Different strategies of photoacclimation by two strains of Emiliania huxleyi (Haptophyta). J Phycol 43: 1209-1222

Titlyanov EA, Titlyanova TV, Yamazato K, van Woesik R (2001) Photo-acclimation dynamics of the coral Stylophora pistillata to low and extremely low light. J Exp Mar Biol Ecol 263:211-225

Trench RK (1979) The cell biology of plant-animal symbiosis. Annu Rev Plant Physiol 30:485-531

Warner ME, Berry-Lowe S (2006) Differential xanthophyll cycling and photochemical activity in symbiotic dinoflagellates in multiple locations of three species of Caribbean coral. J Exp Mar Biol Ecol 339:86-95

Editorial responsibility: Peter Edmunds, Northridge, California, USA
Warner ME, Fitt WK, Schmidt GW (1999) Damage to photosystem II in symbiotic dinoflagellates: a determinant of coral bleaching. Proc Natl Acad Sci USA 96:8007-8012

Warner ME, LaJeunesse TC, Robison JD, Thur RM (2006) The ecological distribution and comparative photobiology of symbiotic dinoflagellates from reef corals in Belize: potential implications for coral bleaching. Limnol Oceanogr 51:1887-1897

West JM, Salm RV (2003) Resistance and resilience to coral bleaching: implications for coral reef conservation and management. Conserv Biol 17:956-967

Winters G, Loya Y, Rottgers R, Beer S (2003) Photoinhibition in shallow-water colonies of the coral Stylophora pistillata as measured in situ. Limnol Oceanogr 48:1388-1393

Submitted: October 11, 2007; Accepted: June 16, 2008

Proofs received from author(s): September 24, 2008 